\title{
High Temperature Corrosion of Inconel 600 in NaCl-KCl Molten Salts
}

\author{
G. Salinas-Solano, ${ }^{1}$ J. Porcayo-Calderon, ${ }^{1,2}$ J. G. Gonzalez-Rodriguez, ${ }^{1}$ \\ V. M. Salinas-Bravo, ${ }^{3}$ J. A. Ascencio-Gutierrez, ${ }^{2}$ and L. Martinez-Gomez ${ }^{2,4}$ \\ ${ }^{1}$ CIICAp, Universidad Autonoma del Estado de Morelos, Avenida Universidad 1001, 62209 Cuernavaca, MOR, Mexico \\ ${ }^{2}$ Instituto de Ciencias Fisicas, Universidad Nacional Autonoma de Mexico, Avenida Universidad s/n, 62210 Cuernavaca, MOR, Mexico \\ ${ }^{3}$ Instituto de Investigaciones Electricas, Avenida Reforma 113, Colonia Palmira, 62490 Cuernavaca, MOR, Mexico \\ ${ }^{4}$ Corrosión y Protección (CyP), Buffon 46, 11590 Mexico City, DF, Mexico
}

Correspondence should be addressed to J. Porcayo-Calderon; jporcayoc@gmail.com

Received 27 May 2014; Revised 20 November 2014; Accepted 9 December 2014; Published 30 December 2014

Academic Editor: Rui Vilar

Copyright (C) 2014 G. Salinas-Solano et al. This is an open access article distributed under the Creative Commons Attribution License, which permits unrestricted use, distribution, and reproduction in any medium, provided the original work is properly cited.

In this work the corrosion resistance of a high content nickel alloy, Inconel 600, was investigated in mixed $\mathrm{NaCl}-\mathrm{KCl}$ salts at 700, 800, and $900^{\circ} \mathrm{C}$ for 100 hours in static air. Investigation was carried out using electrochemical techniques such as polarization curves, rest potential measurements, linear polarization resistance, and electrochemical impedance spectroscopy. Corroded specimens were analyzed by scanning electron microscopy (SEM) and energy-dispersive X-ray spectroscopy (EDS). Electrochemical measurements showed an increased degradation rate of Inconel 600 with increasing test temperature. SEM and EDS analysis show that the damage experienced by Inconel 600 is greater than that determined by electrochemical measurements. This damage was identified as internal corrosion due to the reaction of $\mathrm{Cl}_{2}$ with the alloying elements $(\mathrm{Cr}$ and $\mathrm{Fe})$; however, at $900^{\circ} \mathrm{C}$ the internal damage was minor and it was associated with the nickel content in the alloy.

\section{Introduction}

Problems with process equipment resulting from fireside corrosion have been frequently encountered in waste incinerators and biomass-fired boilers. The major problem is the complex nature of the feed (waste) as well as corrosive impurities which form low-melting point compounds with heavy and alkali metal chlorides which prevent the formation of protective oxide scales and then cause an accelerated degradation of metallic elements [1]. Corrosion occurs on the water wall tubes in the radiant zone, the passes, the screen, evaporator tubes, and super heater tubes. Heat-resistant alloys survive high temperature exposure by growing protective oxide scales. This process involves the selective oxidation of an alloy constituent and necessarily leads to a change in alloy compositions in the subsurface regions. The hot corrosion of alloys is a complex process that typically involves both scale formation and subsurface degradation, including internal precipitation, void formation, phase formation, and phase dissolution [2]. It has been shown that $\mathrm{Cr}$ in a molten chloride environment is not an effective element for corrosion resistance improvement of Fe-based alloys due to chloride salt attack [3-8]. However, on the other hand it has also been suggested that the NiCr-based alloys show better performance than Fe-base alloys. This combined effect has been established in other studies [9-14]. This work addresses the corrosion resistance of Inconel 600 in $\mathrm{NaCl}$ $\mathrm{KCl}$ mixture $(1: 1 \mathrm{M})$ at 700,800 , and $900^{\circ} \mathrm{C}$ for 100 hours in static air.

\section{Experimental}

Chemical composition (\% by weight) of the working electrodes (Inconel 600 ) was $8.26 \% \mathrm{Fe}, 17.20 \% \mathrm{Cr}, 0.49 \% \mathrm{Si}$, and balance Ni. Corrosion tests were carried out using specimens with dimensions of $10 \times 5 \times 3 \mathrm{~mm}$. The specimens were grinded with emery paper until grade 600 and washed with 
water and finally with acetone. For electrical connection, specimens were spot-welded to a Ni20Cr wire. Ceramic tubes were used for isolating the electrical wire from the molten salt; the gap between the ceramic tube and electrical connection wire was filled with refractory cement. Specimen size, surface preparation, and corrosive mixtures were the same for all electrochemical tests. The $\mathrm{NaCl}-\mathrm{KCl}$ corrosion mixture was prepared with analytical grade reagents. Dried chloride salts were first weighted in a 1:1 mole ratio and then subjected to a mechanical milling in an agate mortar to obtain well-mixed reagents. This mixture has a eutectic temperature of $659^{\circ} \mathrm{C}$ [15]. Test temperatures were 700,800 , and $900^{\circ} \mathrm{C}$. A $50 \mathrm{~mL}$ alumina crucible was used for containing the corrosive mixture and placed inside an electrical furnace. When the test temperature was stabilized, the three electrochemical cell electrodes were introduced inside the molten salt. In all experiments, the atmosphere above the melt was static air. Platinum wire ( $1 \mathrm{~mm}$ diameter) was used as counterelectrode and reference electrodes.

Electrochemical measurements carried out were polarization curves $\left(E_{\text {corr }}\right.$ versus $\left.I_{\text {corr }}\right)$, corrosion potential $\left(E_{\text {corr }}\right)$, linear polarization resistance (LPR), and electrochemical spectroscopy impedance (EIS). In LPR technique, a potential polarization of $\pm 20 \mathrm{mV}$ was applied and the variation in current intensity associated with that polarization was measured hourly up to a total of 100 hours. Tafel slopes $\left(b_{a}, b_{c}\right)$ were obtained from the active regions of the corresponding anodic and cathodic curves by scanning the potential from -400 to $1500 \mathrm{mV}$ applying a scanning rate of $1 \mathrm{mV} / \mathrm{s}$. For EIS measurements amplitude of input sine wave of $\pm 10 \mathrm{mV}$ and frequencies from $10,000 \mathrm{~Hz}$ to $0.01 \mathrm{~Hz}$ were used. Electrochemical tests were carried out using an ACM instruments zero-resistance ammeter (ZRA) coupled to a personal computer.

After testing, corroded specimens were mounted in thermosetting resin and polished. The specimen cross-section was analyzed by SEM to investigate the morphology and distribution of reaction products. X-ray mapping and microprobe analysis were carried out using an X-ray energy dispersive (EDX) analyzer associated with a Zeiss DSM960 scanning electron microscope.

\section{Results and Discussion}

3.1. Electrochemical Measurements. Figure 1 shows the potentiodynamic polarization curves for Inconel 600 evaluated in $\mathrm{NaCl}-\mathrm{KCl}$ at different test temperatures. At $700^{\circ} \mathrm{C}$ it is observed that the more anodic behavior $\left(E_{\text {corr }}=-992 \mathrm{mV}\right)$, the highest corrosion resistance $\left(I_{\text {corr }}=0.115 \mathrm{~mA} / \mathrm{cm}^{2}\right)$. At $800^{\circ} \mathrm{C}$ and $900^{\circ} \mathrm{C} I_{\text {corr }}$ values were 0.500 and $0.730 \mathrm{~mA} / \mathrm{cm}^{2}$, respectively. In general, the curves trends show an active corrosion behavior where the test temperature affects both the corrosion potential and corrosion rate. $E_{\text {corr }}$ became more active and $I_{\text {corr }}$ was increased as temperature augmented. Anodic branches did not show a passive zone around $E_{\text {corr }}$ values. However, it should be noted that this behavior corresponds to the beginning of the corrosion process. This trend may change in long-term exposures because either the corrosion process can induce changes in the chemistry of the

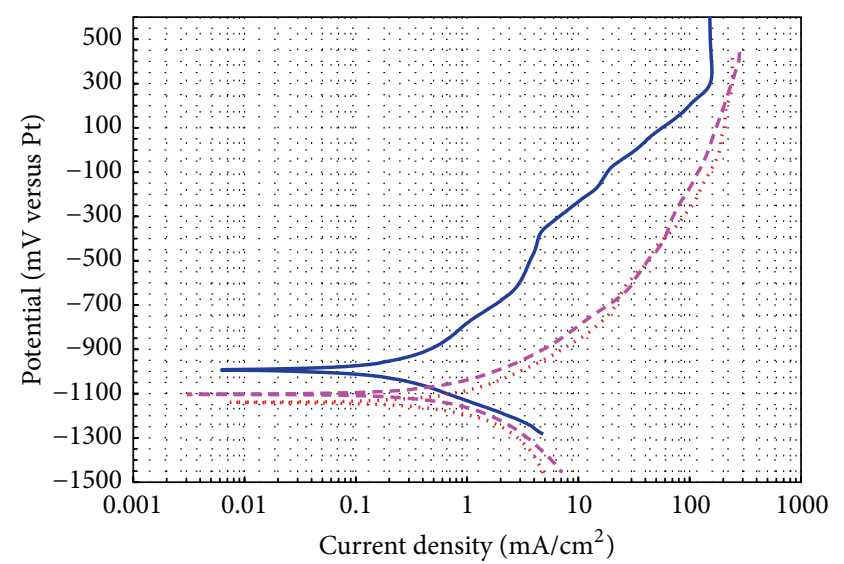

$\begin{array}{ll}\longrightarrow & \text { Inconel } 700^{\circ} \mathrm{C} \\ \ldots \ldots & \text { Inconel } 800^{\circ} \mathrm{C} \\ --- & \text { Inconel } 900^{\circ} \mathrm{C}\end{array}$

FIgURE 1: Polarization plots of Inconel 600 in $\mathrm{NaCl}-\mathrm{KCl}$ at the different temperatures.

TABLE 1: Electrochemical parameters of potentiodynamic polarization tests.

\begin{tabular}{lcccc}
\hline Temperature & $E_{\text {corr }}(\mathrm{mV})$ & $I_{\text {corr }}\left(\mathrm{mA} / \mathrm{cm}^{2}\right)$ & $b_{a}$ & $b_{c}$ \\
\hline $700^{\circ} \mathrm{C}$ & -992 & 0.115 & 394 & 211 \\
$800^{\circ} \mathrm{C}$ & -1139 & 0.500 & 265 & 323 \\
$900^{\circ} \mathrm{C}$ & -1103 & 0.730 & 330 & 439 \\
\hline
\end{tabular}

molten salts making them more aggressive or the material may not be able to regenerate protective oxide layers. Electrochemical parameters obtained from polarization curves are shown in Table 1.

Figure 2 shows progress of $E_{\text {corr }}$ with testing time. One simple way to study the film formation and passivation of materials immersed in molten salts is by monitoring $E_{\text {corr }}$ as a function of time. A rise of potential in the positive direction indicates formation of a passive film and a steady potential indicates that the film remains intact and protective. A drop of potential in the negative direction indicates breaks in the film, dissolution of the film, or no film formation [16]. The test temperature significantly affects $E_{\text {corr }}$ and alloy behavior. Usually an increase in temperature increases the aggressiveness of the molten salts and corrosion resistance will depend on the protective capability of the oxides formed on the alloys. It is observed that, with increasing temperature, $E_{\text {corr }}$ values of Inconel 600 become more active. At $700^{\circ} \mathrm{C}$, $E_{\text {corr }}$ values increased continuously until the end of the test. This behavior indicates that Inconel 600 experienced a continuous corrosion process and it was not able to form a passive layer that protected it from the action of molten salts. At $800^{\circ} \mathrm{C}, E_{\text {corr }}$ values showed a continuous increase, and then an abrupt decrease is observed at 50 hours (around $300 \mathrm{mV}$ ), and after that, there was a slight increase until the end of the test. The initial behavior can be associated with the dissolution of protective oxide layers due to the action of molten salts, and then there is possibly a change in 


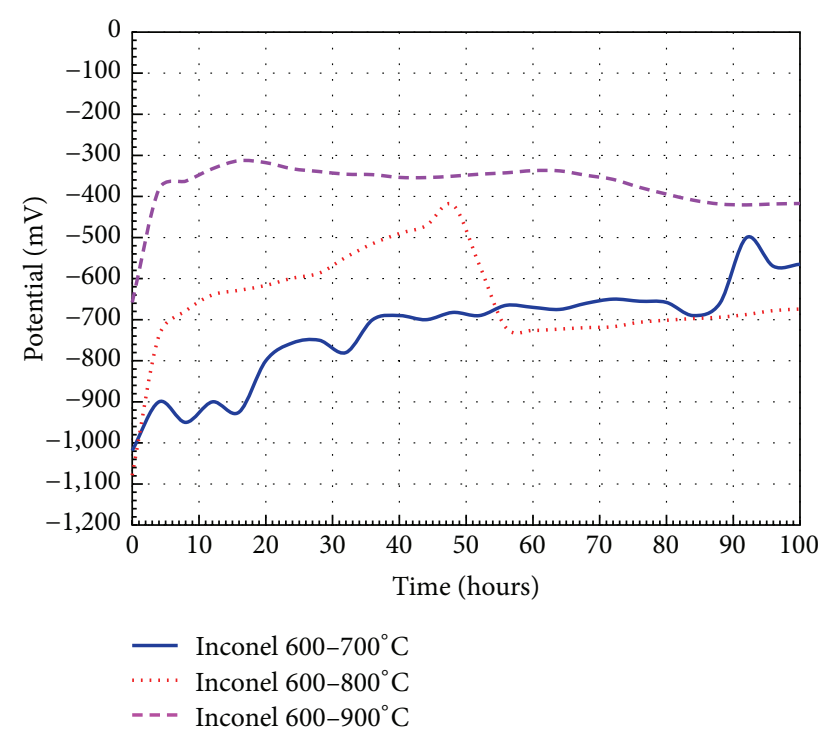

Figure 2: Progress of $E_{\text {corr }}$ values with testing time for Inconel 600 in $\mathrm{NaCl}-\mathrm{KCl}$ at the different temperatures.

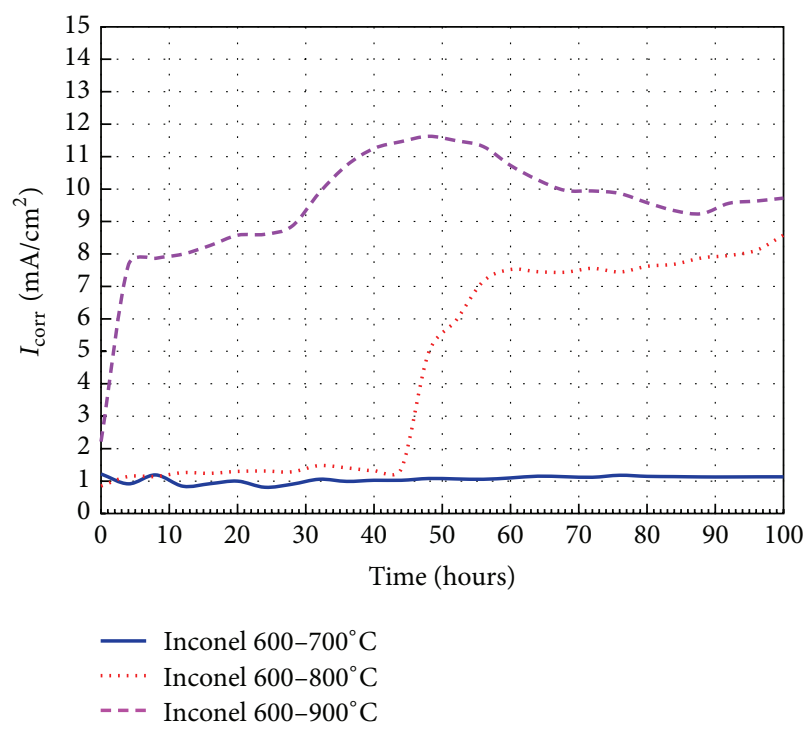

FIGURE 3: Current density $\left(I_{\text {corr }}\right)$ plots for Inconel 600 evaluated in $\mathrm{NaCl}-\mathrm{KCl}$ at different temperatures.

the mechanism of corrosion of the alloy. At $900^{\circ} \mathrm{C}$ in the first 5 hours of testing, there is a sharp increase of $E_{\text {corr }}$ and then it slightly increases until 20 hours; finally, a steady decline is observed until the end of test. This indicates a strong initial attack of the material and a subsequent attempt to form a protective oxide.

Progress of $I_{\text {corr }}$ obtained by linear polarization measurements over time is given in Figure 3. It is known that once polarization resistance is determined, calculation of $I_{\text {corr }}$ requires knowledge of the Tafel constants. These constants can be determined from experimental polarization curves. In the absence of Tafel values, an approximation is sometimes used and the expected error in the calculated value of $I_{\text {corr }}$ should be less than a factor of two [17]. However, when the results show polarization resistance values within the same order of magnitude, it is necessary to use more precise values of the Tafel slopes in order to perform a reliable analysis of the results [18]. Therefore, the values shown in Figure 2 were obtained from the polarization resistance measurements using Stern-Geary equation [17]:

$$
I_{\text {corr }}=\frac{b_{a} b_{c}}{2.303 R_{p}\left(b_{a}+b_{c}\right)},
$$

where $b_{a}$ and $b_{c}$ values were those reported in Table 1 .

The $I_{\text {corr }}$ values trends are consistent with the measurements of $E_{\text {corr }}$ (Figure 2). At $700^{\circ} \mathrm{C}$, Inconel 600 showed an almost constant $I_{\text {corr }}$ around $1.0 \mathrm{~mA} / \mathrm{cm}^{2}$. However, at $800^{\circ} \mathrm{C}$ and $900^{\circ} \mathrm{C} I_{\text {corr }}$ values increased as time elapses. This behavior indicates a continuous corrosion process where the material was not able to form a passive layer that protects it from the action of molten salts. At $800^{\circ} \mathrm{C}$, in the first 44 hours a similar behavior to that shown at $700^{\circ} \mathrm{C}$ is observed; however, after that a sudden increase in the $I_{\text {corr }}$ value was observed, increasing steadily until the end of the test. The sudden increase in the $I_{\text {corr }}$ value can be due to a change in the mechanism of corrosion because the alloy was not able to grow a passive layer on its surface. This can occur when the dissolution-regeneration process of the passive layer modifies the chemical composition of the alloy surface. At $900^{\circ} \mathrm{C}$, in the first 4 hours of testing there is an abrupt increase in $I_{\text {corr }}$ values (from 2.2 to $7.6 \mathrm{~mA} / \mathrm{cm}^{2}$ ) and subsequently a slight increase until 56 hours $\left(11.6 \mathrm{~mA} / \mathrm{cm}^{2}\right)$ and then they decrease towards the end of the test. This indicates a strong initial attack of the material where the molten salts dissolved the passive layer [10].

Experimental impedance spectra, for Inconel 600 in $\mathrm{NaCl}-\mathrm{KCl}$ at different exposure times, are shown in Figure 4. The magnitude of the impedance decreases continuously with time at all temperatures. All experimental spectra have a depressed semicircular shape in the complex impedance plane, with the center under the real axis. At 700 and $800^{\circ} \mathrm{C}$, one time constant at the beginning of the corrosion process (0 hours) was observed. Furthermore, an additional time constant emerged in the rest of the test. At all temperatures, the diameter of capacitive semicircles decreases as time elapses. Reduction of these capacitive loops denotes both an increase in the corrosion rate and the absence of a passive layer on the alloy surface.

It is known that the magnitude of the impedance module and maximum phase angle is associated with a more capacitive response of the protective oxide. In all cases, the plateau zone at the low frequency region was not defined. This shows that, at all test temperatures, the alloy was not able to develop a stable passive layer and hence it had undergone a continuous corrosion process. This behavior indicates that the corrosion process was under charge transfer from the metal to the electrolyte through the double electrochemical layer.

3.2. SEM Analysis. Although electrochemical methods are extremely useful in studying corrosion processes, they alone 


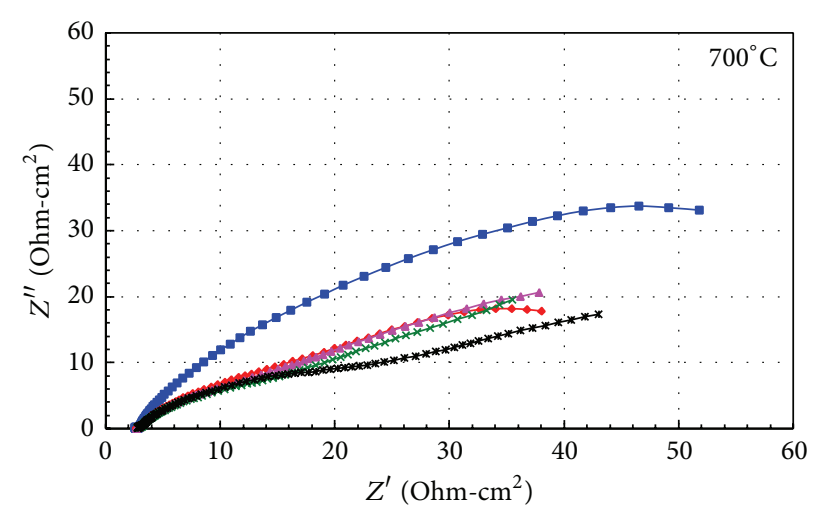

(a)

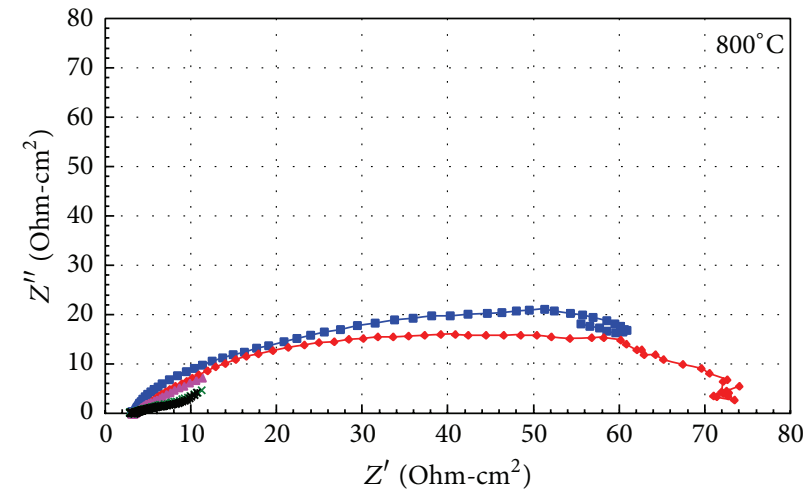

(b)

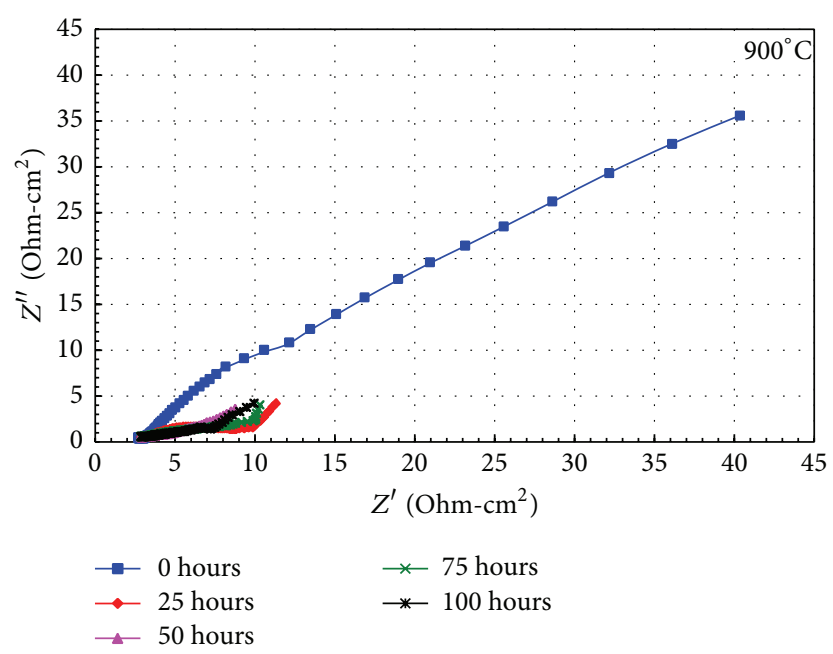

(c)

Figure 4: Progress of Nyquist plots of EIS response of Inconel 600 in NaCl-KCl at different temperatures: (a) $700^{\circ} \mathrm{C}$, (b) $800^{\circ} \mathrm{C}$, and (c) $900^{\circ} \mathrm{C}$.

do not provide enough information to elucidate the mechanism of the system under study. Therefore, the use of complementary techniques like scanning electron microscopy (SEM) and energy-dispersive X-ray spectroscopy (EDS) has been suggested in order to clarify both the morphology of the attack and the chemical composition and distribution of elements present. Combination of these methods provides the information to understand reactions occurring on the surface [19]. Therefore, in this study the cross-section of the working electrodes was studied using SEM and EDS to clarify both the morphology and the elements distribution.

Figure 5 shows the cross-section of Inconel 600 corroded at $700^{\circ} \mathrm{C}$ and the EDS analysis. It is observed that the alloy was not able to form a $\mathrm{Cr}_{2} \mathrm{O}_{3}$ layer on its surface. In this case, the protective oxide had undergone a dissolution process and the dissolution rate was higher than its growing rate. This behavior is consistent with the observations made in the electrochemical measurements. Internal damage was observed indicating that the material degradation was much more severe and this was possibly due to the $\mathrm{Cl}_{2}$ diffusion which favored its direct reaction with the elements of the alloy. The alloy shows a sponge-like internal area with lots of interconnected voids that formed flow channels so the $\mathrm{Cl}_{2}$ penetrates into the material, as reported by other authors [13, $20,21]$. The size of the internal damage zone is approximately 200 microns deep. EDS analysis shows an almost total depletion of $\mathrm{Cr}$ and $\mathrm{Fe}$ and a $\mathrm{Ni}$ enrichment in the spongy area. Formation of the spongy area suggests that $\mathrm{Cl}_{2}$ reacted preferably with $\mathrm{Cr}$ and $\mathrm{Fe}$ or their oxides to form metallic chlorides in gaseous state which diffuse through the channels and precipitated as non-protective oxides in the corrosion product scale. At $800^{\circ} \mathrm{C}$ (Figure 6) the internal damage was greater ( $>700$ microns) than that observed at $700^{\circ} \mathrm{C}$. On the surface of the alloy, the presence of a nonadherent thick $\mathrm{Cr}$ rich layer is observed and below it there is a thin Ni-rich layer. Internal damage observed at $900^{\circ} \mathrm{C}$ was minor $(\approx 500$ microns) than that observed at $800^{\circ} \mathrm{C}$ (Figure 7). Similarly to at 700 and $800^{\circ} \mathrm{C}$, this area shows a depletion of $\mathrm{Cr}$ and $\mathrm{Fe}$ and $\mathrm{Ni}$ enrichment. At $900^{\circ} \mathrm{C}$ a thicker $\mathrm{Cr}$-rich layer ( $\approx 80$ micron) with porous appearance is observed. Possibly the formation of this layer limited the diffusion of aggressive species and thereby internal degradation was less than that observed at $800^{\circ} \mathrm{C}$.

Despite the fact that has been reported that $\mathrm{Ni}$-based alloys have excellent performance in chlorides rich environments $[12,22,23]$, it can be said that the internal damage 


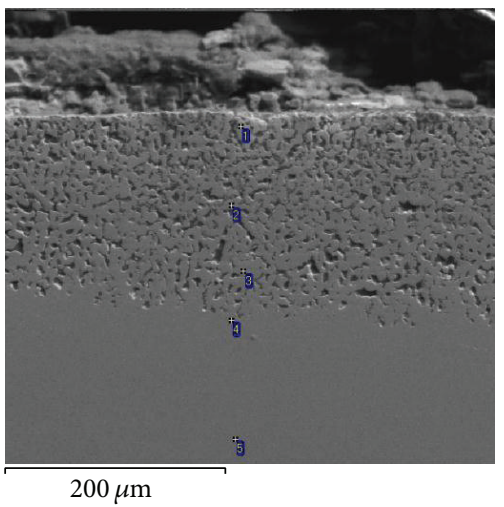

\begin{tabular}{lccc}
\hline Zone & $\mathrm{Cr} \%$ & $\mathrm{Fe} \%$ & $\mathrm{Ni} \%$ \\
\hline Point 1 & 0.611 & 1.483 & 97.906 \\
Point 2 & 1.414 & 1.501 & 97.085 \\
Point 3 & 0.538 & 1.684 & 97.778 \\
Point 4 & 16.441 & 8.442 & 75.117 \\
Point 5 & 17.136 & 8.187 & 74.677 \\
\hline
\end{tabular}

FIGURE 5: SEM image and EDS analysis of a cross-section of Inconel 600 after corrosion test at $700^{\circ} \mathrm{C}$ in $\mathrm{NaCl}-\mathrm{KCl}$ mixture.

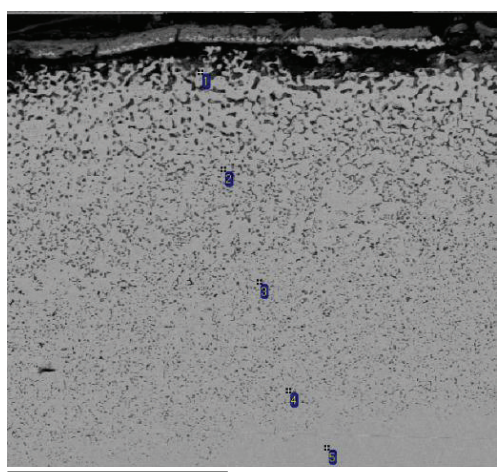

\begin{tabular}{lccc}
\hline \multicolumn{2}{c}{$400 \mu \mathrm{m}$} & & \\
\hline Zone & $\mathrm{Cr} \%$ & $\mathrm{Fe} \%$ & $\mathrm{Ni} \%$ \\
\hline Point 1 & 0.729 & 4.907 & 94.364 \\
Point 2 & 1.910 & 4.268 & 93.822 \\
Point 3 & 8.132 & 5.178 & 86.691 \\
Point 4 & 13.997 & 7.664 & 78.339 \\
Point 5 & 16.988 & 8.291 & 74.720 \\
\hline
\end{tabular}

FIGURE 6: SEM image and EDS analysis of a cross-section of Inconel 600 after corrosion test at $800^{\circ} \mathrm{C}$ in $\mathrm{NaCl}-\mathrm{KCl}$ mixture.

observed in Inconel 600 in molten $\mathrm{NaCl}-\mathrm{KCl}$ is due to the high Fe content in this alloy. Studies with Ni20Cr coatings in Cl-rich molten salts do not show any internal damage such as that observed here $[13,14]$. The corrosion resistance of Inconel 600 is due to the growth of a protective layer of $\mathrm{Cr}_{2} \mathrm{O}_{3}$ on its surface. However, according to the results obtained, the alloy was not able to grow a stable passive layer. It has been reported that the presence of $\mathrm{Cr}$ is responsible for the low corrosion resistance of materials in chloride salts and oxidizing environments. This is explained because chromium oxide is more soluble than both oxides of iron and nickel in molten $\mathrm{NaCl}-\mathrm{KCl}[15]$. The Ni-enrichment in the spongy

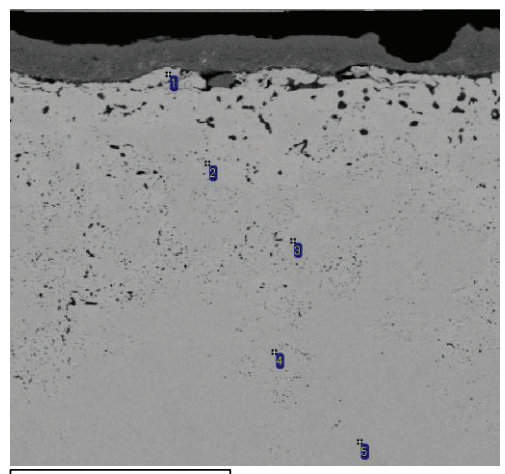

$$
400 \mu \mathrm{m}
$$

\begin{tabular}{lccc}
\hline Zone & $\mathrm{Cr} \%$ & $\mathrm{Fe} \%$ & $\mathrm{Ni} \%$ \\
\hline Point 1 & 1.121 & 5.453 & 93.426 \\
Point 2 & 16.404 & 8.018 & 75.578 \\
Point 3 & 12.989 & 6.777 & 80.234 \\
Point 4 & 7.883 & 6.658 & 85.459 \\
Point 5 & 17.295 & 8.115 & 74.590 \\
\hline
\end{tabular}

FIGURE 7: SEM image and EDS analysis of a cross-section of Inconel 600 after corrosion test at $900^{\circ} \mathrm{C}$ in $\mathrm{NaCl}-\mathrm{KCl}$ mixture.

zone shows that both $\mathrm{Cr}$ and $\mathrm{Fe}$ were the main elements that reacted with the molten $\mathrm{NaCl}-\mathrm{KCl}$ salts. Therefore, the reactions that resulted in the degradation of Inconel 600 are

$$
\begin{gathered}
\mathrm{Cr}_{2} \mathrm{O}_{3}+6 \mathrm{Cl}^{-}=2 \mathrm{CrCl}_{3}+2 \mathrm{O}^{2-}+\frac{1}{2} \mathrm{O}_{2} \\
2 \mathrm{Fe}_{2} \mathrm{O}_{3}+8 \mathrm{Cl}^{-}=4 \mathrm{FeCl}_{2}+5 \mathrm{O}^{2-}+\frac{1}{2} \mathrm{O}_{2}
\end{gathered}
$$

These reactions suggest that metallic oxides are converted into metallic chloride in environments with low oxygen partial pressure; that is, this can only occur at the interface metal-molten salt or in the spongy area observed in Figures 5-7. The metallic chlorides have high vapor pressures and can move easily toward regions with higher oxygen partial pressure where the reverse reaction is favored; that is, metallic chlorides are oxidized to form nonprotective metallic oxides. The oxide layer thus formed is porous and nonprotective so that the corrosion rate is increased.

The appearance shown by the SEM micrographs indicates that the magnitude of the attack is greater than that assumed by the electrochemical measurements. This can occur when there are gaseous species that can diffuse to regions like the spongy zone where molten salts cannot do it easily. Then it is possible that in addition to reactions between molten salt and the protective oxides, there were reactions with gaseous species, such as $\mathrm{Cl}_{2}$, and the alloying elements, as follows [22, 23]:

$$
\begin{gathered}
2 \mathrm{Cr}+3 \mathrm{Cl}_{2}=2 \mathrm{CrCl}_{3} \\
\mathrm{Fe}+\mathrm{Cl}_{2}=\mathrm{FeCl}_{2}
\end{gathered}
$$

These reactions may justify the inconsistencies resulting from electrochemical measurements and the actual damage observed by SEM. Similar reactions can occur with the $\mathrm{Ni}$ 


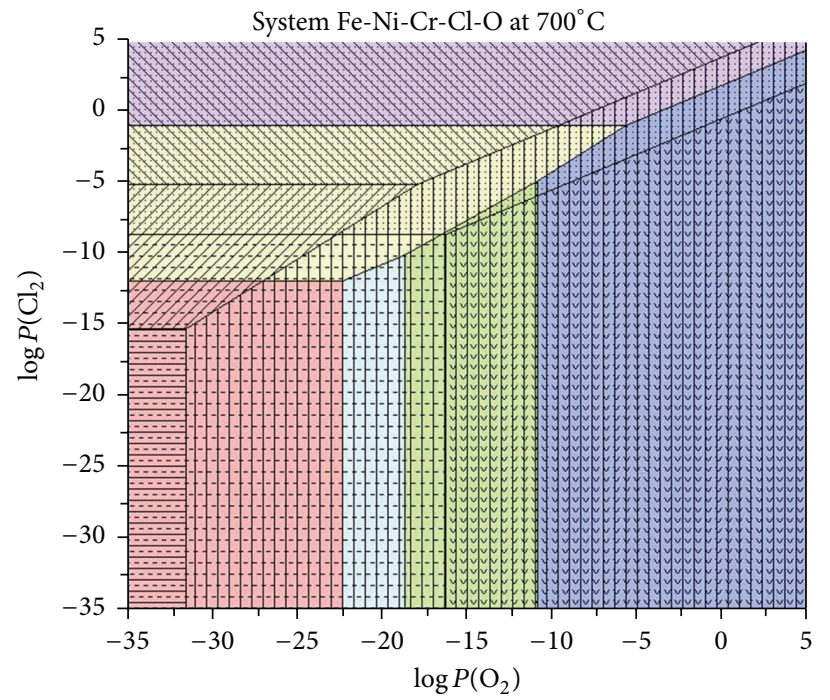

(a)

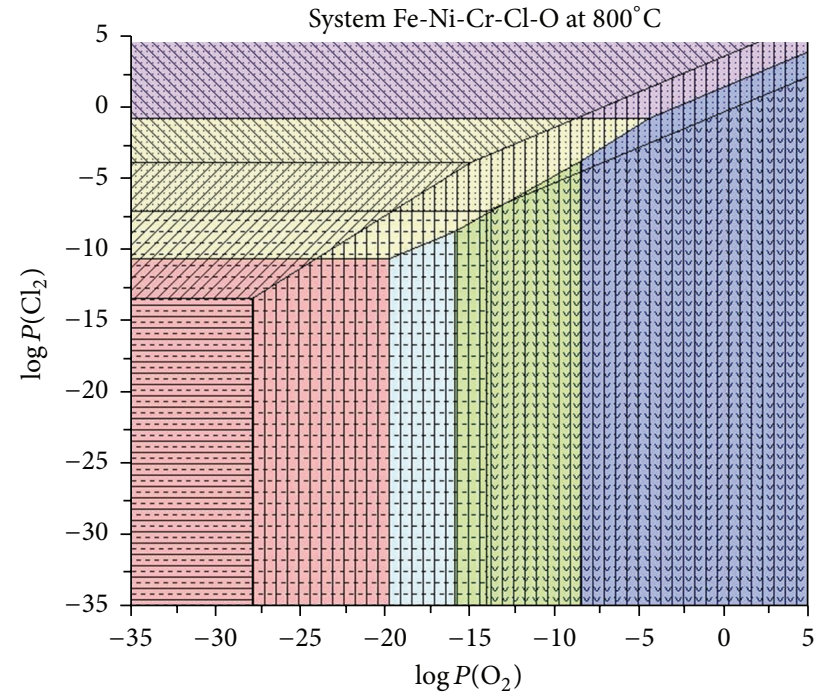

(b)

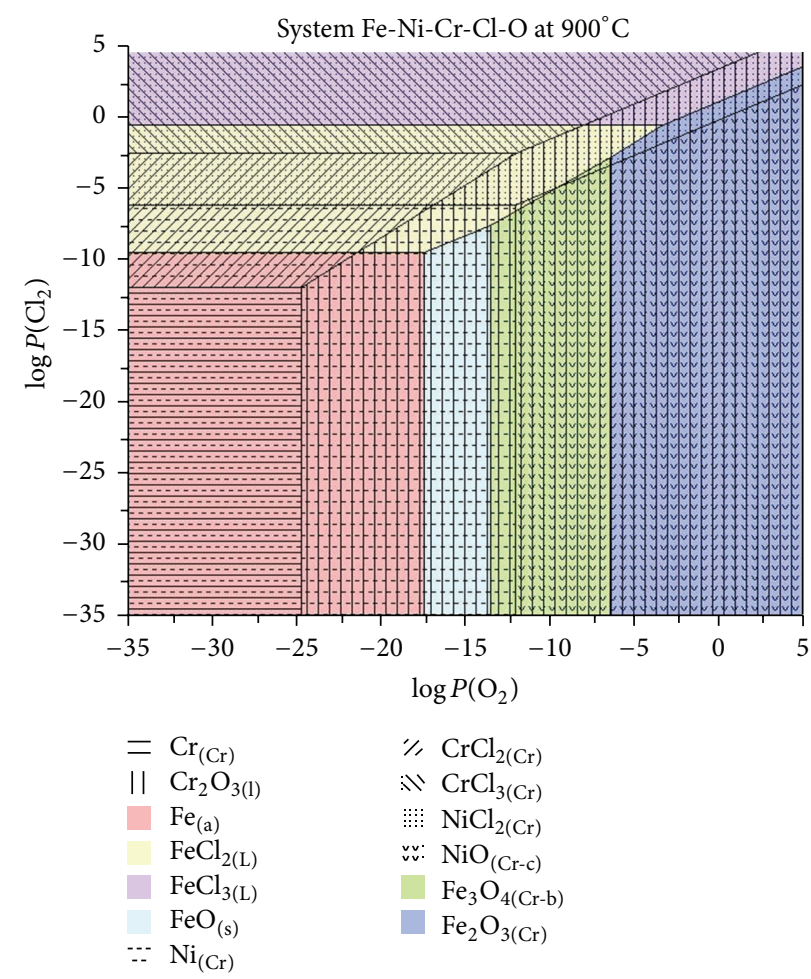

(c)

Figure 8: Thermodynamic stability diagrams for Fe-Cr-Ni-Cl-O at (a) $700^{\circ} \mathrm{C}$, (b) $800^{\circ} \mathrm{C}$, and (c) $900^{\circ} \mathrm{C}$.

oxides to form $\mathrm{NiCl}_{2}$. However, it is known that $\mathrm{NiCl}_{2}$ has a higher thermodynamic stability and a lower vapor pressure compared with iron and chromium chlorides at the same temperature. On the other hand, the solubility measurements of oxide scales in Cl-rich molten salts show that $\mathrm{NiO}$ is less soluble than the Fe and Cr oxides [24].

The corrosion results described above imply clearly that a high $\mathrm{Ni}$ content is very effective in improving the corrosion resistance of Inconel 600 in $\mathrm{NaCl}-\mathrm{KCl}$ melt while $\mathrm{Cr}$ plays a detrimental role under the same conditions. This is explained because the breakdown of the protective oxide can occur by dissolution into the molten salts and the degradation rate can be fast if the oxide has a high solubility.

Considering that $\mathrm{Cl}_{2}$ and $\mathrm{O}_{2}$ are the main species of the $\mathrm{NaCl}-\mathrm{KCl}$-air system that contribute to the degradation of materials in waste incinerators environments, the construction of phase stability diagrams of these species with the main elements of the alloy is a useful tool for understanding 
TABLE 2: Chemical reactions and equilibrium constants for the Fe-Cr-Ni-Cl-O system.

\begin{tabular}{|c|c|c|c|c|}
\hline \multirow{2}{*}{ Number } & \multirow{2}{*}{ Reaction } & \multicolumn{3}{|c|}{$\log _{10} K$} \\
\hline & & $700^{\circ} \mathrm{C}$ & $800^{\circ} \mathrm{C}$ & $900^{\circ} \mathrm{C}$ \\
\hline 1 & $\mathrm{Cr}_{(\mathrm{s})}+\mathrm{Cl}_{2}=\mathrm{CrCl}_{2(\mathrm{~s})}$ & 15.2418 & 13.2619 & 11.7406 \\
\hline 2 & $\mathrm{Fe}_{(\mathrm{s})}+\mathrm{Cl}_{2}=\mathrm{FeCl}_{2(1)}$ & 11.8886 & 10.4408 & 9.2427 \\
\hline 3 & $\mathrm{Ni}_{(\mathrm{s})}+\mathrm{Cl}_{2}=\mathrm{NiCl}_{2(\mathrm{~s})}$ & 8.5735 & 7.0918 & 5.8697 \\
\hline 4 & $2 \mathrm{Fe}_{(\mathrm{s})}+\mathrm{O}_{2}=2 \mathrm{FeO}_{(\mathrm{s})}$ & 22.3934 & 19.7013 & 17.4531 \\
\hline 5 & $2 \mathrm{Ni}_{(\mathrm{s})}+\mathrm{O}_{2}=2 \mathrm{NiO}_{(\mathrm{s})}$ & 16.3501 & 13.9913 & 12.0392 \\
\hline 6 & $6 \mathrm{FeO}_{(\mathrm{s})}+\mathrm{O}_{2}=2 \mathrm{Fe}_{3} \mathrm{O}_{4(\mathrm{~s})}$ & 18.7011 & 15.8875 & 13.5643 \\
\hline 7 & $3 \mathrm{FeCl}_{2(\mathrm{l})}+2 \mathrm{O}_{2}=\mathrm{Fe}_{3} \mathrm{O}_{4(\mathrm{~s})}+3 \mathrm{Cl}_{2}$ & 7.2749 & 6.1735 & 5.2338 \\
\hline 8 & $4 \mathrm{Fe}_{3} \mathrm{O}_{4(\mathrm{~s})}+\mathrm{O}_{2}=6 \mathrm{Fe}_{2} \mathrm{O}_{3(\mathrm{~s})}$ & 10.9159 & 8.4684 & 6.4435 \\
\hline 9 & $2 \mathrm{Cr}_{2} \mathrm{O}_{3(\mathrm{~s})}+4 \mathrm{Cl}_{2}=4 \mathrm{CrCl}_{2(\mathrm{~s})}+3 \mathrm{O}_{2}$ & -33.7821 & -30.4114 & -27.1388 \\
\hline 10 & $2 \mathrm{Fe}_{2} \mathrm{O}_{3(\mathrm{~s})}+4 \mathrm{Cl}_{2}=4 \mathrm{FeCl}_{2(\mathrm{l})}+3 \mathrm{O}_{2}$ & -13.3384 & -11.0541 & -9.1263 \\
\hline 11 & $4 \mathrm{Cr}_{(\mathrm{s})}+3 \mathrm{O}_{2}=2 \mathrm{Cr}_{2} \mathrm{O}_{3(\mathrm{~s})}$ & 94.7492 & 83.4590 & 74.1012 \\
\hline 12 & $2 \mathrm{FeO}_{(\mathrm{s})}+2 \mathrm{Cl}_{2}=2 \mathrm{FeCl}_{2(\mathrm{~L})}+\mathrm{O}_{2}$ & 1.3838 & 1.1802 & 1.0322 \\
\hline 13 & $2 \mathrm{NiO}_{(\mathrm{s})}+2 \mathrm{Cl}_{2}=2 \mathrm{NiCl}_{2(\mathrm{~s})}+\mathrm{O}_{2}$ & 0.7969 & 0.1923 & -0.2999 \\
\hline 14 & $2 \mathrm{CrCl}_{2(\mathrm{~s})}+\mathrm{Cl}_{2}=2 \mathrm{CrCl}_{3(\mathrm{~s})}$ & 5.0434 & 3.6087 & 2.1961 \\
\hline 15 & $2 \mathrm{FeCl}_{2(\mathrm{~L})}+\mathrm{Cl}_{2}=2 \mathrm{FeCl}_{3(\mathrm{~L})}$ & 0.9457 & 0.5304 & 0.1967 \\
\hline 16 & $2 \mathrm{Cr}_{2} \mathrm{O}_{3(\mathrm{~s})}+6 \mathrm{Cl}_{2}=4 \mathrm{CrCl}_{3(\mathrm{~s})}+3 \mathrm{O}_{2}$ & -23.6952 & -23.1939 & -22.7465 \\
\hline 17 & $2 \mathrm{Fe}_{2} \mathrm{O}_{3(\mathrm{~s})}+6 \mathrm{Cl}_{2}=4 \mathrm{FeCl}_{3(\mathrm{~L})}+3 \mathrm{O}_{2}$ & -11.4470 & -9.9933 & -8.7329 \\
\hline
\end{tabular}

the corrosion behavior at high temperature in this environment. Figure 8 shows the phase stability diagrams for the Fe$\mathrm{Cr}-\mathrm{Ni}-\mathrm{Cl}-\mathrm{O}$ system at 700,800 , and $900^{\circ} \mathrm{C}$. The procedure to generate the diagrams is described elsewhere [25]. Table 2 shows the set of chemical reactions used for their calculation.

Regarding the metallic elements that constitute the Inconel 600, it is observed that from a thermodynamic perspective $\mathrm{Ni}$ is the most stable element. Therefore, $\mathrm{Ni}$ will remain immune in $\mathrm{O}_{2}$ and $\mathrm{Cl}_{2}$ environments where the $\mathrm{Fe}$ and $\mathrm{Cr}$ would be corroding continuously. Therefore, in environments found in garbage incinerators in the temperature of 700$900^{\circ} \mathrm{C}$, the Ni-rich alloys will show better performance compared with those richer in Fe or Cr. This analysis is consistent with reported studies where they indicate that $\mathrm{Ni}$ or its alloys show better performance in chlorides-rich environments compared with $\mathrm{Fe}$ and $\mathrm{Cr}$ or their alloys [22]. However, according to $\mathrm{Li}$ et al. [7], despite the fact that $\mathrm{Cr}_{2} \mathrm{O}_{3}$ is very stable at very low $\mathrm{O}_{2}$ partial pressures, the partial pressure of $\mathrm{Cl}_{2}$ can increase significantly in the oxide-melt interface so that the metallic chlorides can become stable phases instead of the oxides. Moreover, they suggest that because the vapor pressure of chlorides is too high, they diffuse toward the meltgas interface and can precipitate as nonprotective oxides; repeating this cycle leads to a process defined as "active oxidation." This analysis justifies the depletion in $\mathrm{Fe}$ and $\mathrm{Cr}$ and the Ni-enrichment observed in the alloy.

\section{Conclusions}

The corrosion resistance of Inconel 600 in $\mathrm{NaCl}-\mathrm{KCl}$ at $700^{\circ} \mathrm{C}, 800^{\circ} \mathrm{C}$, and $900^{\circ} \mathrm{C}$ was studied by electrochemical techniques an SEM and EDS analysis. Corrosive attack was documented by SEM and EDX analysis. Polarization plots showed that corrosion rate $\left(I_{\text {corr }}\right)$ increases with temperature. In a time base of $100 \mathrm{~h}$, corrosion rate of Inconel 600 remains steady at $700^{\circ} \mathrm{C}$ but increases at 800 and $900^{\circ} \mathrm{C}$. With electrochemical impedance measurements, SEM and EDS analysis showed that increase of corrosion rate of Inconel 600 at $800^{\circ} \mathrm{C}$ and $900^{\circ} \mathrm{C}$ was due to the absence of a passive layer on the alloy and the formation of an internal zone with voids and depleted in $\mathrm{Cr}$ and $\mathrm{Fe}$. Analysis of the thermodynamic stability diagrams for Fe-Cr-Ni-Cl-O at $700^{\circ} \mathrm{C}, 800^{\circ} \mathrm{C}$, and $900^{\circ} \mathrm{C}$ supports the fact that $\mathrm{Ni}$ remains immune and $\mathrm{Fe}$ and $\mathrm{Cr}$ will dissolve continuously in melt $\mathrm{NaCl}-\mathrm{KCl}$ environments. Results described indicate that both $\mathrm{Cr}$ and $\mathrm{Fe}$ content of Inconel 600 play a detrimental role in molten $\mathrm{NaCl}-\mathrm{KCl}$ environments at high temperature. The internal degradation experienced by the alloy was due to the preferential attack of chromium and iron oxides and to the direct reaction of $\mathrm{Cl}_{2}$ with the alloying elements. The lower thermodynamic stability of iron and chromium chlorides contributed to the catastrophic attack of Inconel 600 .

\section{Conflict of Interests}

The authors declare that there is no conflict of interests regarding the publication of this paper.

\section{Acknowledgments}

Financial support from Consejo Nacional de Ciencia y Tecnología (CONACYT, México) (project CVU 270660) and Ph.D. scholarship given to G. Salinas-Solano (Registration no. 219258) are gratefully acknowledged. 


\section{References}

[1] F. J. Kohl, G. J. Santoro, C. A. Stearns, G. C. Fryburg, and D. E. Rosner, "Theoretical and experimental studies of the deposition of $\mathrm{Na}_{2} \mathrm{SO}_{4}$ from seeded combustion gases," Journal of the Electrochemical Society, vol. 126, no. 6, pp. 1054-1061, 1979.

[2] D. J. Young and B. Gleeson, "Alloy phase transformations driven by high temperature corrosion processes," Corrosion Science, vol. 44, no. 2, pp. 345-357, 2002.

[3] Y. Shinata and Y. Nishi, "NaCl-induced accelerated oxidation of chromium," Oxidation of Metals, vol. 26, no. 3-4, pp. 201-212, 1986.

[4] N. Hiramatsu, Y. Uematsu, T. Tanaka, and M. Kinugasa, "Effects of alloying elements on $\mathrm{NaCl}$-induced hot corrosion of stainless steels," Materials Science and Engineering A, vol. 120-121, no. 1, pp. 319-328, 1989.

[5] Y. S. Li, M. Sanchez-Pasten, and M. Spiegel, "High temperature interaction of pure Cr with KCl," Materials Science Forum, vol. 461-464, pp. 1047-1054, 2004.

[6] F. Wang and Y. Shu, "Influence of Cr content on the corrosion of $\mathrm{Fe}-\mathrm{Cr}$ alloys: the synergistic effect of $\mathrm{NaCl}$ and water vapor," Oxidation of Metals, vol. 59, no. 3-4, pp. 201-214, 2003.

[7] Y. S. Li, Y. Niu, and W. T. Wu, "Accelerated corrosion of pure $\mathrm{Fe}, \mathrm{Ni}, \mathrm{Cr}$ and several Fe-based alloys induced by $\mathrm{ZnCl}_{2}-$ $\mathrm{KCl}$ at $450^{\circ} \mathrm{C}$ in oxidizing environment," Materials Science and Engineering A, vol. 345, no. 3, pp. 964-970, 2003.

[8] Y. Kawahara, "High temperature corrosion mechanisms and effect of alloying elements for materials used in waste incineration environment," Corrosion Science, vol. 44, no. 2, pp. 223-245, 2002.

[9] Y. S. Li, Y. Niu, and W. T. Wu, "Accelerated corrosion of pure Fe, $\mathrm{Ni}, \mathrm{Cr}$ and several $\mathrm{Fe}$-based alloys induced by $\mathrm{ZnCl}_{2}-\mathrm{KCl}$ at 450 ${ }^{\circ} \mathrm{C}$ in oxidizing environment," Materials Science and Engineering A, vol. 345, no. 1-2, pp. 64-71, 2003.

[10] W. M. Lu, T. J. Pan, K. Zhang, and Y. Niu, “Accelerated corrosion of five commercial steels under a $\mathrm{ZnCl}_{2}-\mathrm{KCl}$ deposit in a reducing environment typical of waste gasification at 673-773 K," Corrosion Science, vol. 50, no. 7, pp. 1900-1906, 2008.

[11] T. J. Pan, C. L. Zeng, and Y. Niu, "Corrosion of three commercial steels under $\mathrm{ZnCl}_{2}-\mathrm{KCl}$ deposits in a reducing atmosphere containing $\mathrm{HCl}$ and $\mathrm{H}_{2} \mathrm{~S}$ at $400-500^{\circ} \mathrm{C}$," Oxidation of Metals, vol. 67, no. 1-2, pp. 107-127, 2007.

[12] K. Yamada, Y. Tomono, J. Morimoto, Y. Sasaki, and A. Ohmori, "Hot corrosion behavior of boiler tube materials in refuse incineration environment," Vacuum, vol. 65, no. 3-4, pp. 533540, 2002.

[13] J. Porcayo-Calderon, O. Sotelo-Mazon, V. M. Salinas-Bravo, C. D. Arrieta-Gonzalez, J. J. Ramos-Hernandez, and C. CuevasArteaga, "Electrochemical performance of $\mathrm{Ni20Cr}$ coatings applied by combustion powder spray in $\mathrm{ZnCl}_{2}-\mathrm{KCl}$ molten salts," International Journal of Electrochemical Science, vol. 7, no. 2, pp. 1134-1148, 2012.

[14] J. Porcayo-Calderon, O. Sotelo-Mazon, M. Casales-Diaz, J. A. Ascencio-Gutierrez, V. M. Salinas-Bravo, and L. MartinezGomez, "Electrochemical study of Ni20Cr coatings applied by $\mathrm{HVOF}$ process in $\mathrm{ZnCl}_{2}-\mathrm{KCl}$ at high temperatures," Journal of Analytical Methods in Chemistry, vol. 2014, Article ID 503618, 10 pages, 2014.

[15] Y. S. Li, M. Spiegel, and S. Shimada, "Corrosion behaviour of various model alloys with $\mathrm{NaCl}-\mathrm{KCl}$ coating," Materials Chemistry and Physics, vol. 93, no. 1, pp. 217-223, 2005.
[16] I. Gurappa, "Characterization of different materials for corrosion resistance under simulated body fluid conditions," Materials Characterization, vol. 49, no. 1, pp. 73-79, 2002.

[17] E. E. Stansbury and R. A. Buchanan, Fundamentals of Electrochemical Corrosion, ASM International, Materials Park, Ohio, USA, 2000.

[18] A. Pardo, S. Feliu Jr., M. C. Merino, R. Arrabal, and E. Matykina, "Electrochemical estimation of the corrosion rate of magnesium/aluminium alloys," International Journal of Corrosion, vol. 2010, Article ID 953850, 8 pages, 2010.

[19] Y. van Ingelgem, A. Hubin, and J. Vereecken, "Investigation of the first stages of the localized corrosion of pure copper combining EIS, FE-SEM and FE-AES," Electrochimica Acta, vol. 52, no. 27, pp. 7642-7650, 2007.

[20] D. A. Shores and B. P. Mohanty, "Role of chlorides in hot corrosion of a cast Fe-Cr-Ni alloy. Part II: thermochemical model studies," Corrosion Science, vol. 46, no. 12, pp. 2909-2924, 2004.

[21] B. P. Mohanty and D. A. Shores, "Role of chlorides in hot corrosion of a cast Fe-Cr-Ni alloy. Part I. Experimental studies," Corrosion Science, vol. 46, no. 12, pp. 2893-2907, 2004.

[22] A. Ruh and M. Spiegel, "Thermodynamic and kinetic consideration on the corrosion of $\mathrm{Fe}, \mathrm{Ni}$ and $\mathrm{Cr}$ beneath a molten $\mathrm{KCl}$ $\mathrm{ZnCl}_{2}$ mixture," Corrosion Science, vol. 48, no. 3, pp. 679-695, 2006.

[23] Y. S. Li and M. Spiegel, "Models describing the degradation of $\mathrm{FeAl}$ and $\mathrm{NiAl}$ alloys induced by $\mathrm{ZnCl}_{2} \mathrm{KCl}$ melt at $400-450{ }^{\circ} \mathrm{C}$," Corrosion Science, vol. 46, no. 8, pp. 2009-2023, 2004.

[24] T. Ishitsuka and K. Nose, "Stability of protective oxide films in waste incineration environment-solubility measurement of oxides in molten chlorides," Corrosion Science, vol. 44, no. 2, pp. 247-263, 2002.

[25] J. J. Ramos-Hernandez, J. Porcayo-Calderon, V. M. SalinasBravo, C. D. Arrieta-Gonzalez, J. G. Gonzalez-Rodriguez, and L. Martinez-Gomez, "Phase stability diagrams for high temperature corrosion processes," Mathematical Problems in Engineering, vol. 2013, Article ID 542061, 7 pages, 2013. 

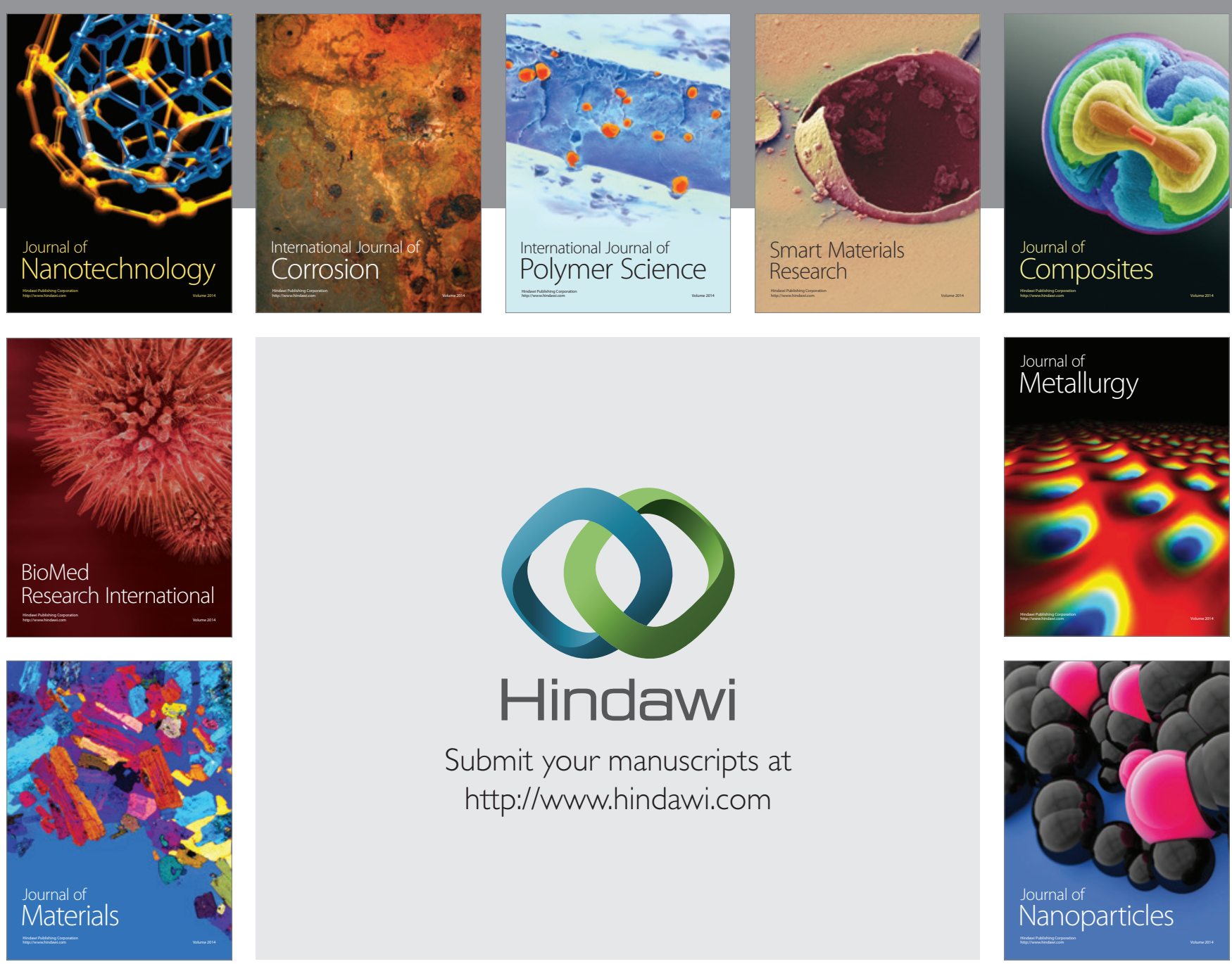

Submit your manuscripts at http://www.hindawi.com
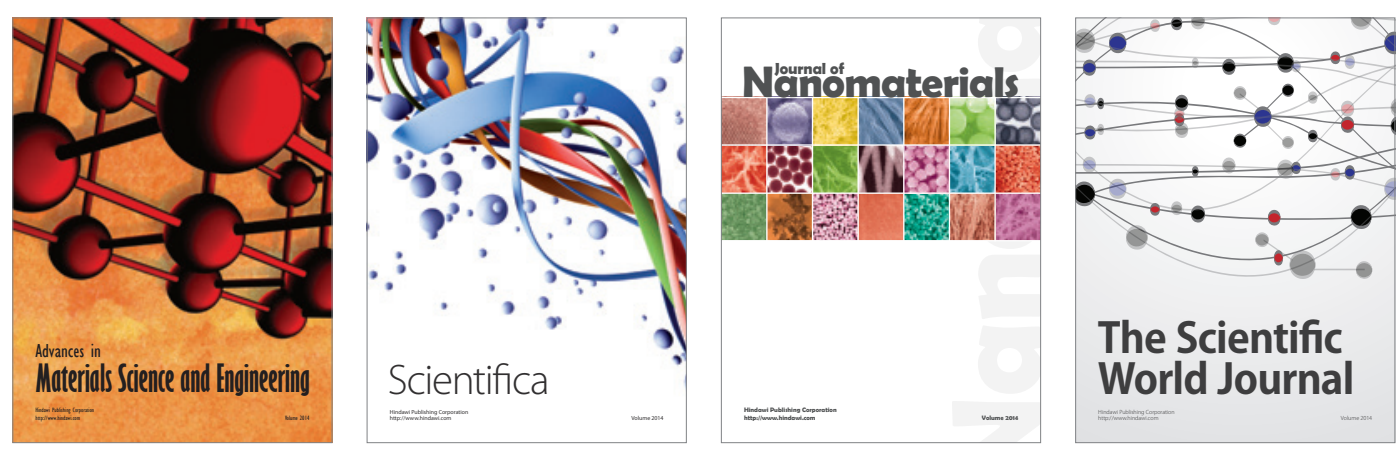

\section{The Scientific World Journal}
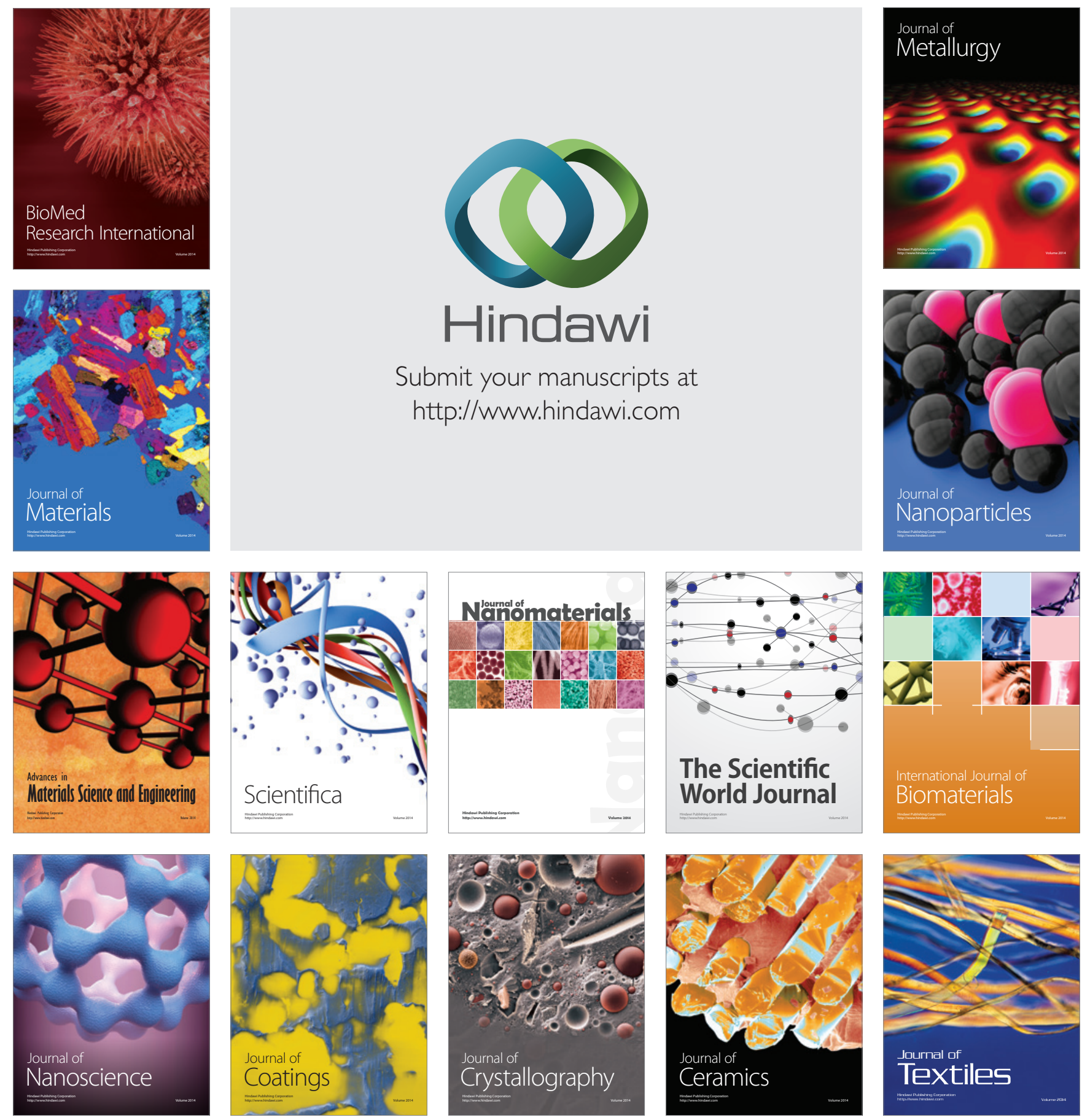